\title{
PRELIMINARY STUDY ON LIPID PROFILE WITH RELATION TO TOTAL ANTIOXIDANT CAPACITY AND SOME HEMATOLOGICAL AND BIOCHEMICAL CHANGES OF PRE-POST-PARTUM BUFFALO HEIFERS AT ASSIUT CITY
}

\author{
GHADA A.E. MOHAMED*; EMAN M.ABD- ELNASER ${ }^{*}$ and HANAN K. ELSAYED ${ }^{* *}$ \\ *Animal Health Research Institute, Assiut Branch. \\ ** Dept. of Animal Medicine, Faculty of Veterinary Medicine, Assiut University, Assiut, Egypt. \\ Email: eman_191069@yahoo.com
}

\section{ABSTRACT}

Received at:23/12/2014

Accepted: 20/1/2015
The objectives of this study were to evaluate the relation between lipid profile and total antioxidant capacity (TAC) and to investigate the changes in some hematological and biochemical parameters in buffalo heifers during pre and postpartum period. The study was conducted on 30 buffalo heifers from a buffalo's farm that belongs to Assiut City, Egypt. These pregnant buffaloes were followed until delivery. Blood samples were taken at 3 weeks pre-partum (late pregnancy) and one month post-partum (early lactation). Two types of samples were collected, whole blood samples for hematological picture, and serum samples for biochemical analysis which included total proteins, albumin, globulins, AST, ALT, triglycerides, total cholesterol, HDL-C, LDL-C, and total antioxidant capacity (TAC). The hematological indices including mean values of RBC, Hb, PCV, MCV, and MCH, TLC, lymphocyte \% and neutrophil \% revealed significant decrease in the early lactation period if compared with late pregnancy mean values. There were significant increase in total proteins, albumin and globulins in the early lactating group compared with late pregnancy group. The mean values of AST, revealed significant increase in the early lactating group compared with late pregnancy group. A significant decrease in the mean values of triglycerides was observed in the early lactating period compared with late pregnancy results. The mean value of total cholesterol, HDL-C and total antioxidant capacity (TAC) revealed significant increase, in the early lactating group compared with late pregnancy group. There were a positive correlation between Total antioxidant capacity (TAC), albumin, total cholesterol and HDL-C.

Key words: lipid profile, total antioxidant capacity, buffalo heifers, Hematological picture, biochemical alterations

\section{INTRODUCTION}

Buffaloes are the main source of good quality meat and milk in the valley of the River Nile in Egypt and some other developing countries despite this species is mostly reared under harsh socioeconomic conditions and shows low productive and reproductive potentials (GOVS, 2005 and El-Wishy, 2006).

During the transition period from late pregnancy to early lactation, energy requirement that is needed for fetal growth and milk synthesis increases dramatically exceeding the amount of energy the cow can obtain from dietary sources (Castillo et al., 2005).

This dramatic increase in energy requirements makes dairy animal highly susceptible to negative energy balance (NEB). The metabolic adaptation to NEB requires interactions of metabolic fuels and its failure may occur in various tissues such as liver and adipose tissue (Herdt, 2000).

During NEB, periparturient cows meet their energy requirements by lipomobilization syndrome, i.e. in the dry period and early lactation, is accompanied by typical changes in the serum concentration of lipid parameters, particularly changes in triglycerides, the total cholesterol and High and low density lipoprotein (HDL-C and LDL-C) concentrations (Pysera and Opalka, 2000; Turk et al., 2004, 2005, 2008; and Wathes et al., 2013).

Under physiological conditions, the body usually has sufficient antioxidant reserves to cope with the production of free radicals (Miller et al., 1993; and Castillo et al., 2001), which are produced continuously during metabolism and may increase as a result of pathological and other circumstances (Roth, 2000). However, when free radical generation 
exceeds the body's antioxidant production capacity, oxidative stress develops. In dairy cows, the peripartum and early lactation periods are especially critical and present considerable physiological challenges to homeostasis by imposing significant metabolic stressors that may contribute to the onset of diverse disorders (Goff and Horst, 1997).

Oxidative stress can be monitored with several biomarkers and several methods have been developed to assess total antioxidant capacity in view of the difficulty of measuring each antioxidant component separately and their interactions in serum (Cao and Prior, 1998; Niki and Noguchi, 2000 Young, 2001; and Castillo et al., 2006). As a single measure, total antioxidant status (TAS) provides more biologically relevant information that may more effectively describe the dynamic equilibrium between prooxidants and antioxidants in the plasma compartment (Ghiselliet al., 2000) although it has received little attention in clinical oxidative stress profiling.

The objectives of this study were to evaluate the relation between lipid profile and total antioxidant capacity and to study the changes in some hematological and biochemical parameters in buffalo heifers during pre and post-partum period.

\section{MATERIALS and METHODS}

\section{Animals:}

The study was conducted on 30 buffalo heifers pregnant for the first time from a buffalo's farm that belongs to Assiut City, Egypt. These pregnant buffaloes were followed until delivery. The samples were taken at 3 weeks prepartum (late pregnancy) and one month postpartum (early lactation).

\section{Samples:}

-Whole blood samples: $10 \mathrm{ml}$ of blood was drawn from jugular vein of each calf in clean centrifuge tubes containing EDTA as an anticoagulant for complete blood picture evaluation.

- Serum sample: $10 \mathrm{ml}$ of blood was drawn from the jugular vein of each calf in clean vacutainer tube without anticoagulant. Sera were separated by centrifugation and stored at $-20 \mathrm{C}$ until used (Coles, 1986). The serum was clear and free from haemolysis.

\section{Hematological picture:}

Total red blood cell count (TRBCs T/l), hemoglobin volume ( $\mathrm{Hb} \mathrm{g} / \mathrm{l})$, packed cell volume (PCV\%), mean corpuscular volume $(\mathrm{MCV} / \mathrm{fl})$ and mean corpuscular hemoglobin $(\mathrm{MCH} / \mathrm{pg}$ ), were determined using a fully automated blood cell counter analyser, Abbott cell- dyne 1700, in the department of animal medicine Faculty of Veterinary Medicine-Assiut university,
Assiut. Total leucocytic count (TLCx103/ $\mathrm{mm}^{3}$ blood), Lymphocyte \%, Monocyte \%, Neutrophil\%, Eosinophil \%, and Basophil \%, were determined (Coles, 1986).

\section{Biochemical analysis:}

Measurements of total proteins (TP), albumin (ALB), aspartate amino transferees (AST) activity, alanine aminotransferase (ALT) activity, triglycerides, total cholesterol, high density lipoprotein (HDL-C) and low density lipoprotein (LDL-C) concentrations, were carried out using reagent test kits supplied commercially by Biodiognestic, Egypt. Spectrophotometeric assay was performed using spectrophotometer in the department of Animal Medicine- Faculty of Veterinary Medicine Assiut University, Assuit Egypt.

Total Antioxidant capacity (TAC):

TAC was measured by colorimetric method according to (Koracevic et al., 2001). The determination of the antioxidative capacity is performed by the reaction of antioxidants in the sample with a defined amount of exogenously provide hydrogen peroxide (H2O2). The antioxidant in the sample eliminate a certain amount of the provided hydrogen peroxide. The residual $(\mathrm{H} 2 \mathrm{O} 2)$ is determined calorimetrically by an enzymatic reaction which involves the conversion of 3, 5, dichloro-2- hydroxyl benzensulphonate to a colored product.

\section{Statistical analysis:}

Data were analyzed using the packaged SPSS program for windows version 10.01 (SPSS, 2000 Inc., Chicago, IL). Data were presented as mean \pm standard deviation (SD). Differences between groups were determined by the one way analysis of variance (ANOVA). Significance level was set at $\mathrm{P} \leq 0.01$ and $\mathrm{P} \leq 0.05$.

\section{RESULTS}

The hematological indices including $\mathrm{RBC}, \mathrm{Hb}, \mathrm{PCV}$, $\mathrm{MCV}$, and $\mathrm{MCH}$ are shown in table (1). Mean values revealed significant $(p \leq 0.05)$ decrease in $R B C$, in the early lactation group compared with late pregnancy group, while highly significant decrease $(p \leq 0.01)$ at the $\mathrm{Hb}$, results of total and differential leucocytic count were shown in table (1). Mean values revealed highly significant decrease at ( $\mathrm{p} \leq 0.01$ ) in the TLC, lymphocyte \% and neutrophil $\%$ in the early lactating group compared with late pregnancy group. Non-significant changes in monocyte \%, Esoniphile \% and Basophile \% were reported in both groups. The results of total proteins albumin and globulins were shown in table (2). Mean values revealed significant increase at $(p \geq 0.05)$ in total proteins, albumin and globulins (which calculated mathematically), in the early lactating group compared with late pregnancy group. 
The mean values of AST, revealed significant increase at $(p \geq 0.05)$, in the early lactating group compared with late pregnancy group table (2). The results of triglycerides, total cholesterol, high density lipoprotein (HDL-C), low density lipo protein (LDLC) concentrations, and total antioxidant capacity (TAC) were shown in table (2). Mean values revealed significant decrease at $(p \leq 0.05)$ in the triglycerides in the early lactating group compared with late pregnancy group. The mean value of total cholesterol revealed highly significant ( $p \geq 0.01$ ) increase, also, HDL-C showed significant increase at $(p \geq 0.05)$ in the early lactating group compared with late pregnancy group. Non-significant change in LDL-C in both groups was reported. Mean values of total antioxidant capacity (TAC) revealed significant increase at $(p \geq 0.01)$ in the early lactating group compared with late pregnancy group.

There were a positive correlation between total antioxidant capacity (TAC) and albumin ( $\mathrm{r}=0.420$, $\mathrm{p}=<0.001)$, total cholesterol $(\mathrm{r}=0.342, \mathrm{p}=<0.001)$ and HDL-C $(r=0.321, p=<0.001)$.

Table 1: Mean values $( \pm \mathrm{SD})$ of hematological indices in late pregnancy and early lactation period.

\begin{tabular}{ccc}
\hline parameter & Late pregnancy & Early lactation \\
\hline RBCs (T/l) & $5.9 \pm 0.29$ & $5.33 \pm 0.69^{*}$ \\
\hline Hb $(\mathbf{g m} / \mathbf{d l})$ & $11.19 \pm 0.70$ & $9.69 \pm 0.63^{* *}$ \\
\hline PCV (\%) & $40.66 \pm 1.3$ & $31.58 \pm 1.9^{* *}$ \\
\hline MCV(fl) & $52.28 \pm 2.1$ & $47.73 \pm 3.4 * *$ \\
\hline MCH(pg) & $17.93 \pm 0.82$ & $15.62 \pm 0.52^{* *}$ \\
\hline TLCx 103/mm ${ }^{3}$ & $12.45 \pm 0.91$ & $10.22 \pm 1.51 * *$ \\
\hline Lymphocyte \% & $67.20 \pm 2.4$ & $60.40 \pm 4.5 * *$ \\
\hline Monocyte \% & $13.90 \pm 1.9$ & $14.00 \pm 2.6 \mathrm{~ns}$ \\
\hline Neutrophil \% & $22.60 \pm 0.83$ & $14.10 \pm 0.85 * *$ \\
\hline Eosinophil\% & $5.40 \pm 0.67$ & $2.20 \pm 1.22 \mathrm{~ns}$ \\
\hline Basophil \% & $0.66 \pm 0.51$ & $0.33 \pm 0.51 \mathrm{~ns}$ \\
\hline
\end{tabular}

*significant difference at $0.05, * *$ significant difference at 0.01, ns non-significant

Table 2: Mean values $( \pm \mathrm{SD})$ of measured biochemical parameters and lipid profile in late pregnancy and early lactation period.

\begin{tabular}{ccc}
\hline parameter & Late pregnancy & Early lactation \\
\hline Total proteins $(\mathbf{g m} / \mathbf{d l})$ & $6.79 \pm 0.40$ & $7.82 \pm 0.51^{*}$ \\
\hline Albumin $(\mathbf{g m} / \mathbf{d l})$ & $3.81 \pm 0.06$ & $4.32 \pm 0.08^{*}$ \\
\hline Globulins $(\mathbf{g m} / \mathbf{d l})$ & $2.97 \pm 0.07$ & $3.5 \pm 0.06^{*}$ \\
\hline AST $(\mathbf{I U} / \mathbf{l})$ & $67.90 \pm 15.98$ & $80.02 \pm 18.81^{*}$ \\
\hline ALT $(\mathbf{I U} / \mathbf{l})$ & $44.37 \pm 12.78$ & $49.79 \pm 13.09 \mathrm{~ns}$ \\
\hline TAC $(\mathbf{m m o l} / \mathbf{l})$ & $0.57 \pm 0.05$ & $0.66 \pm 0.12^{* *}$ \\
\hline Triglyceriedes $(\mathbf{m m o l} / \mathbf{l})$ & $0.58 \pm 0.17$ & $0.56 \pm 0.13^{*}$ \\
\hline Total cholesterol $(\mathbf{~ m m o l} / \mathbf{l})$ & $2.94 \pm 0.31$ & $3.51 \pm 0.13 * *$ \\
\hline HDL-C $(\mathbf{m m o l} / \mathbf{l})$ & $2.14 \pm 0.01$ & $2.82 \pm 0.06^{*}$ \\
\hline LDL-C $(\mathbf{m m o l} / \mathbf{l})$ & $2.06 \pm 0.04$ & $2.42 \pm 0.05 \mathrm{~ns}$ \\
\hline
\end{tabular}

\footnotetext{
*significant difference at $0.05, *$ significant difference at 0.01, ns non-significant
} 


\section{DISCUSSION}

During the periparturient periods the energy requirement significantly increases, essentially to support milk production, and the physiological adaptation to this condition is represented by the implementation of metabolic activities and by an extensive mobilization of body fat reserves, particularly in early lactation (Castillo et al., 2005, 2006; Kowalska and Jankowiak, 2009; and Roth 2000).

The hematological parameters were significantly altered in cows during the peri-parturient periods. RBCs count showed a significant decrease at ( $\mathrm{p} \leq 0.05)$ in the early lactating period when compared with the late pregnant one. The $\mathrm{Hb}, \mathrm{PCV}, \mathrm{MCV}$, and $\mathrm{MCH}$, showed a significant decrease at $(\mathrm{p} \leq 0.01)$ in the early lactating group in comparing with the late pregnant group. This result is similar to what observed by Găvan, et al. (2010) who attributed the reduction in RBCS count, $\mathrm{MCV}$, and $\mathrm{MCH}$ to deficiency of iron during peri-parturient periods, that resulted in a decreased MCV (microcytosis) because cells undergo an extra division due to inadequate hemoglobin concentration (Roy et al., 2010). PCV\% and $\mathrm{Hb}(\mathrm{gm} / \mathrm{dl})$ showed a significant decrease during peri-parturient periods, that was attributed to anemia due to stress of pregnancy and parturation (Daramola et al., 2004).

Total leucocytic count $\left(10^{3} / \mathrm{mm}\right)$, lymphocyte \%and neutrophile $\%$ showed a significant decrease at ( $p$ $\leq 0.01$ ) in the early lactating group compared with late pregnancy group. In fact, near parturition, usually the total WBCs, lymphocyte and neutrophils mean values were increased due to the antepartum rise in cortisol (Preisler et al., 2000 and Kim et al., 2005).

Mean values of serum total proteins, were significantly elevated at $(p \geq 0.05)$ in the early lactating group than the late pregnant one. This may be attributed to both elevation of serum albumin and globulins. Serum total proteins as parturition approach usually decreased may be due to the fact that the fetus synthesizes all its proteins from the amino acids derived from the dam, and growth of the fetus increases exponentially reaching a maximum level, especially in muscles, during late pregnancy (Jainudee, and Hafez, 1994), and also due to the haemoconcentration and water losses occurred following parturition (Ghanem et al., 2012).

Serum albumin showed a significant increase at ( $\mathrm{p}$ $\geq 0.05$ ) in the early lactating group. This result could be attributed to endogenous production of antioxidants, such as albumin, in an attempt to cope with the increase in lipoperoxide production, especially one week before calving and early postpartum (Mantovani et al., 2010).
Serum globulins showed a significant increase at $(p \geq 0.05)$ in the early lactating group. The reduction of globulins in the late pregnancy group and its increase in the early lactation group associated mainly with the immunological response to provide the newly born calf with sufficient globulins in colostrum (Janku et al., 2005).

AST activity was numerically higher during early post parturient periods in comparison with its value at calving (indicating that hepatic metabolism might be more stressed and tissue catabolism was more pronounced during this period Greenfield, (2000) However, because enzyme activities were within the normal range, integrity and functionality of liver tissue was obviously maintained during these periods. A similar trend was observed by Reist et al. (2003) for Holstein dairy cows, where AST activity was lowest pre - partum and reached its peak during the first week post parturient.

The observed peripartum increase in serum enzymes indicated increased hepatic effort during this period. It has previously been reported that reduced dry matter intake around parturition may lead to hepatic lipidosis that alters the normal function of the liver (Greenfield et al., 2000 and Drackley, 2002), although in our study the increase in ALT was small and certainly not significant.

Mean values of total antioxidant capacity (TAC) revealed significant increase at $(p \geq 0.01)$ in the early lactating group compared with late pregnancy group. TA capacity concentrations obtained in both late pregnancy and early lactating groups of buffaloes were in accordance with the values obtained in previous reports of peripartuent cows (Castillo et al., 2003; Bozukluhan et al., 2013 and Mousa and Galal 2013) were they found TAC concentration was significantly lower before calving and the highest concentration of TAC was observed 8 weeks postpartum (Castillo et al., 2006). The lowest mean value of TAC ( 3 weeks before calving) was coincident with the absence of vitamins and mineral supplementation, i.e., exogenous antioxidants, during the dry period. As regards antioxidant defense, the observed relationship between TAC and albumin confirms the role played by this protein as a component with antioxidant capacity (Castillo et al., 2001), and this role is especially important in the period when the animals did not receive vitamin/mineral supplementation Sordillo, and Raphael (2013).

Triglycerides Mean values revealed significant decrease at $(p \leq 0.05)$ in the early lactating group compared with late pregnancy group. As reported previously, Triglycerides concentration significantly decreased at calving and remained at the lowest concentration until the eighth week of lactation. The reasons for such disturbances probably are in 
triglycerides accumulation in the liver (Bremmer et al., 2000 and Turk et al., 2004, 2005); and in triglycerides taking up by the mammary gland for milk fat synthesis and secretion (Bernard et al., 2008 and Mantovani et al., 2010).

The mean value of total cholesterol revealed significant increase at $(p \geq 0.01)$ in the early lactating group compared with late pregnancy group. The descending trend in the serum total cholesterol concentration in late pregnant buffaloes compared to lactating buffaloes was observed as mentioned before by (Nath, 2005). The current study revealed lower levels of serum total cholesterol and HDL-C, in buffalo heifers when compared with those reported by Tajik and Nazifi (2001), which may be attributed to variation in the breed and age of the animals investigated.

The serum total cholesterol concentration was minimum following calving and got build up as the lactation progresses Grummer (1993). The higher level of cholesterol with advancement of lactation was a physiological adjustment to meet the lactation requirements.

Serum HDL-C showed a significant increase at ( $\mathrm{p}$ $\geq 0.05$ ) in the early lactating group compared with late pregnancy group. The decrease in HDL-C may be attributed to depressed lipoprotein lipase (LPL) as there is a positive association between LPL and HDLC (Bernard et al., 2008). Total cholesterol and HDL$\mathrm{C}$ were significantly lower one week around parturition with the lowest values one week prior to calving and increased after parturition and reached significantly higher values at 4 and 8 weeks postpartum (Mantovani et al., 2010).

These lipids change present typical patterns of lipomobilisation syndrome during transition period and were also demonstrated in previous investigations reported by Mazur et al. (1988), Grummer (1993) and Turk et al. (2008).

Total antioxidant capacity (TAC) showed significant positive correlation with albumin $(\mathrm{r}=0.420$, $\mathrm{p}=<0.001)$, total cholesterol $(\mathrm{r}=0.342, \mathrm{p}=<0.001)$ and HDL-C (0.321, $\mathrm{p}=<0.001)$. Our results suggest that lipid mobilization and oxidative stress are part of a complex metabolic adaptation to low energy balance which reaches equilibrium later in advanced lactation.

\section{REFERENCES}

Bernard, L.; Leroux, C. and Chilliard, Y. (2008): Expression and nutritional regulation of lipogenic genes in the ruminant lactating mammary gland. Adv. Exp. Med. Biol. 606, 67-108.
Bozukluhan, K.; Atakisi, E. and Atakisi, O. (2013): Nitric oxide levels, total antioxidant and oxidant capacity in cattle with foot-andmouth-disease kafkas. Univ. Vet Fak. Derg., 19(1): 179-181.

Bremmer, D.R.; Bertics, S.J.; Besong, A. and Grummer, R.R. (2000): Changes in hepatic microsomal triglyceride transfer protein and Triglyceride in periparturient dairy cattle. Journal of Dairy Science 83, 2252-2260.

Cao, G. and Prior, R.L. (1998): Comparison of different analytical methods for assessing total antioxidant capacity of human serum. Clinical Chemistry 44, 1309-1315.

Castillo, C.; Benedito, J.L.; Lopez-Alonso, M.; Miranda, M. and Hernandez, J. (2001): Importancia del estr_esoxidativo en Ganado vacuno: en relaci_on con el estadofisiol_ogico (pre nez y parto) y la nutrici_on. Archivos de MedicinaVeterinaria 33, 5-20.

Castillo, C.; Hernandez, J.; Lopez-Alonso, M.; Miranda, and M., Benedito, J.L. (2003): Values of plasma lipid hydroperoxides and total antioxidant status in healthy dairy cows: preliminary observations. Archives of Animal Breeding 46, 227-233.

Castillo, C.; Hernandez, J.; Bravo, A.; Lopez Alonso, M.; Pereira, V. and Benedito, J.L. (2005): Oxidative status during late pregnancy and early lactation in dairy cows. The Veterinary Journal, 169, 286-292.

Castillo, C.; Hernandez, J.; Valverde, I.; Pereira, V.; Sotillo, J.; Lopez Alonso, M. and Benedito, J.L. (2006): Plasma malonaldehyde (MDA) and total antioxidant status (TAS) during lactation in dairy cows. Research in Veterinary Science, 80, 133-139.

Coles, E.H. (1986): Veterinary clinical pathology WB Saunders Company. Philadelphia and London.

Daramola, J.O.; Adeloye, A.A. and Soladoye, O. (2004): Changes in some hematological and biochemical parameters during pre-partum and postpartum periods in female West African dwarf goats. J. Agric. Sci. 10: 53-60.

Drackley, J.K. (2002): Transition cow management and periparturient metabolic disorders. In: Kaske, M., Scholz, H., H€oltershinken, M. (Eds.), Recent Developments and Perspectives in Bovine Medicine. Klinikf€ur Rinderkrankheiten, Tier€arztliche Hochschule, Hannover, pp. 224-235.

El-Wishy, A.B. (2006): The post-partum buffalo II Acyclicity and anestrus. Animal Reproduction Science, 97:216-236.

Găvan, C.; Retea, C. and Motorga, V. (2010): Changes in the hematological profile of Holstein primiparous in peri-parturient period and in early to mid-lactation. Anim. Sci. Biotech. 43: 244-246. 
Ghanem, M.M.A.; Mahmoud, M.E.A.; Abd El-Raof, Y.M.A. and El-Attar, H.M.A. (2012): Metabolic profiles test for monitoring the clinical, haematological and biochemical alterations in cattle during periparturient period. Benha Veterinary Medical Journal, VOL. 23, NO. 2, DEC. 2012: 13-23.

Ghiselli, A.; Serafini, M.; Natella, F. and Scaccini, C. (2000): Total antioxidant capacity as a tool to assess redox status: critical view and experimental data. Free Radical Biological Medicine 29, 1106- 1114.

Goff, J.P. and Horst, R.L. (1997): Physiological changes at parturition and their relationship to metabolic disorders. Journal of Dairy Science 80, 1260-1268.

GOVS (2005): Technical veterinary report., General Organization of Veterinary Service, Egypt.

Grummer, R.R. (1993): Etiology of lipid-related metabolic disorders in periparturient dairy cows. Journal of Dairy Science. 76, 3882-3896.

Greenfield, R.B.; Cecava, M.J.; Johnson, T.R. and Donkin, S.S. (2000): Impact of dietary protein amount and rumen undegradability on intake, peripartum liver triglyceride, plasma metabolites and milk production in transition dairy cattle. Journal of Dairy Science 83, 703-710.

Herdt, T.H. (2000): Variability characteristics and test selection in herdlevel nutritional and metabolic profile testing. Veterinary Clinics of North America: Food Animal Practice 16, 387-403.

Jainudee, M.R. and Hafez, E.S.E. (1994): Gestation Prenatal Physiology and Parturition. In, Hafez ESE (Ed): Reproduction in Farm Animals. Lea and Febiger, Philadelphia. Pp. 247-283

Janku, L., Pavlata, L., Mišurová, L., Filipek, J., Pechová, A.; Kim, I.H.; Na, K.J. and Yang, M.P. (2005): Immune responses during the peripartum period in dairy cows with postpartum endometritis. J. Reprod Dev. 51: 757-764.

Kim, I.H.; Na, K.J. and Yang, M.P. (2005): Immune responses during the peripartum period in dairy cows with postpartum endometritis. J. Reprod Dev. 51: 757-764.

Koracevic, D. and Koracevic, G. (2001): Colorimetric method for determination of total antioxidant capacity. J. Clin. Pathol. 54, 356-361.

Kowalska, J. and Jankowiak, D. (2009): Changes of reduction oxidation balance in pregnant ruminants. Postepy Biochemii, 55, 323-328.

Mazur, A.; Gueux, E.; Chiliad, Y. and Rayssiguier, Y. (1988): Changes in plasma lipoproteins and liver fat content in dairy cows during early lactation. J. Anim. Physiol. Anim. Nutr. 59, 233-237.
Mantovani, R.; Sgorlon, S.; Marinelli, L.; Bailoni, L.; Bittante, G. and Gabai, G. (2010): Oxidative stress indicators and metabolic adaptations in response to the omission of the dry period in dairy cows. Journal of Dairy Rechearch 77, 273-279.

Miller, J.K.; Brzezinska-Slebodzinska, E. and Madsen, F.C. (1993): Oxidative stress, antioxidants and animal function. Journal of Dairy Science 76, 2812-2823.

Mousa, S.A. and Galal, M.KH. (2013): Alteration in Clinical, Hemobiochemical and Oxidative Stress Parameters in Egyptian Cattle Infected with Foot and Mouth Disease (FMD). J. Anim. Sci. Adv., 2013, 3(9): 485-491

Nath, H.C. (2005): Serum cholesterol and protein in pre, peri and postpartum cows. Indian Vet. J. 82: 519-521.

Niki, E. and Noguchi, N. (2000): Evaluation of antioxidant capacity is being measured by which method? IUBMB Life 50, 323-329.

Preisler, M.T.; Weber, P.S.; Tempelman, R.J.; Erskine, R.J.; Hunt, H. and Burton, J.L. (2000): Glucocorticoid receptor downregulation in neutrophils of peri-parturient cows. Am J Vet Res. 61: 14-19.

Pysera, B. and Opalka, A. (2000): The effect of gestation and lactation of dairy cows on lipid and lipoprotein patterns and composition in serum during winter and summer feeding. Journal Animal Feed Science 9, 411-424.

Reist, M.; Erdin, D.; Euw, D.V.; Tschuemperlin, K.; Leuenberger, H.; Delavaud, C.; Chilliard, Y.; Hammon, H. M.; Kuenzi, N. and Blum, J.W. (2003): Concentrate feeding strategy in lactating dairy cows: metabolic and endocrine changes with emphasis on leptin. Journal of Dairy Science. 86: 1690-1706.

Roth, E. (2000): Oxygen free radicals and their clinical implications. Acta Chirurgica Hungarica 36, 302-305.

Roy, S.; Roy, M. and Mishra, S. (2010): Hematological and biochemical profile during gestation period in sahiwal cows. Vet. World 3: $26-28$.

Sordillo, L.M. and Raphael, W. (2013): Significance of metabolic stress, lipid mobilization, and inflammation on transition cow disorders. The Veterinary Clinics of North America: Food Animal Practice, 29, 267-278.

SPSS (2000): Sample Power statistics, SPSS 11.5, Syntax reference guide for SPSS Base. SPSS Inc., 233 South Wacker Drive, Chicago.

Tajik, J. and Nazifi, S. (2001): 'Serum concentrations of lipids and lipoproteins and their correlations together and with thyroid hormones in Iranian water buffalo (Bulbalusbulbalis)', Asian Journal of Animal Sciences 5, 196-201.

Turk, R.; Juretic, D.; Geres, D.; Turk, N.; Rekic, B.; Simeon-Rudolf, V. and Svetina, A. (2004): 
Serum paraoxonase activity and lipid parameters in the early postpartum period of dairy cows. Research in Veterinary Science, 76, 57-61.

Turk, R.; Juretic, D.; Geres, D.; Turk, N.; Rekic, B.; Simeon-Rudolf, V.; Robic, M. and Svetina, A. (2005): Serum paraoxonase activity in dairy cows during pregnancy. Research in Veterinary Science 79:15-18.

Turk, R.; Juretić, D.; Gerěs, D.; Svetina, A.; Turk, N. and Flegar-Meštrić, Z. (2008): Influence of oxidative stress and metabolic adaptation on PON1 activity and MDA level in transition dairy cows. Animal Reproduction Science, 108, 98-106.

Wathes, D.C.; Clempson, A.M. and Pollott, G.E. (2013): Associations between lipid metabolism and fertility in the dairy cow. Reproduction, Fertility and Development, 25, 48-61.

Young, I.S. (2001): Measurement of total antioxidant capacity. Journal of clinical pathology 54, 339.

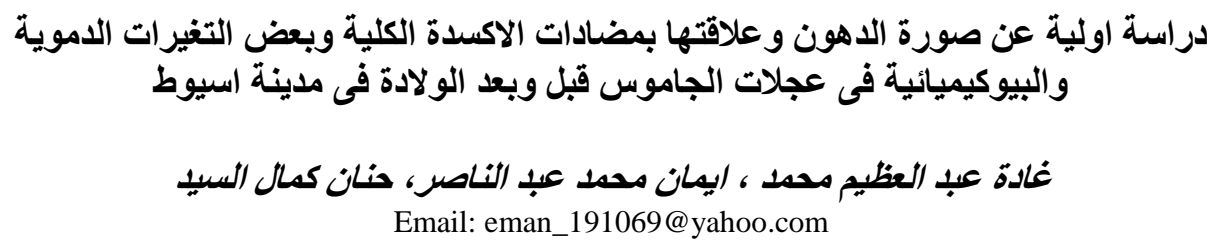

Email: eman_191069@yahoo.com

\begin{abstract}
استهدفت الدراسه معرفه العلاقه بين صوره الدهون ومضادات الاكسده الكلية ودراسه بعض التوات التغيرات الدمويه والبيوكيميائيه

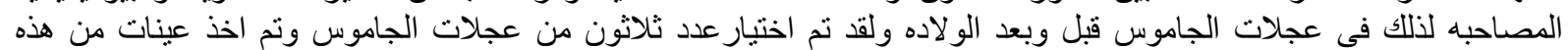

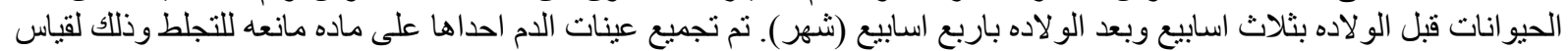

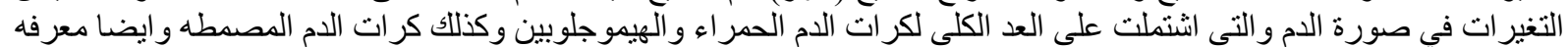

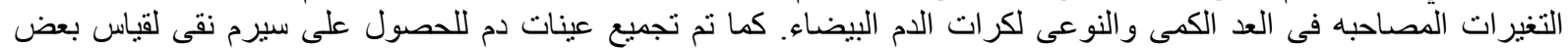

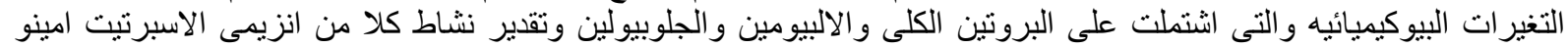

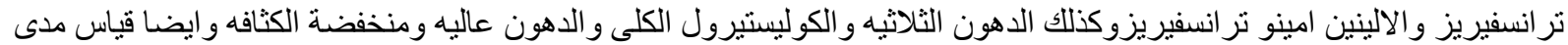

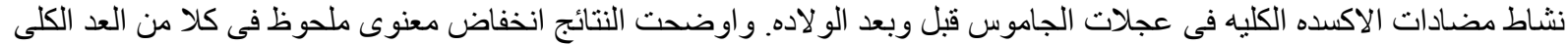

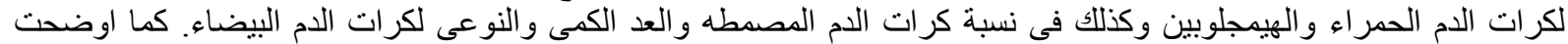

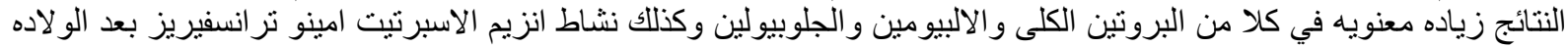

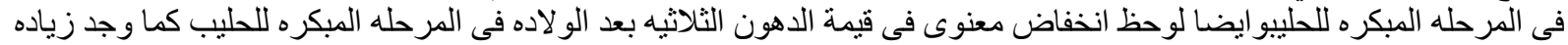

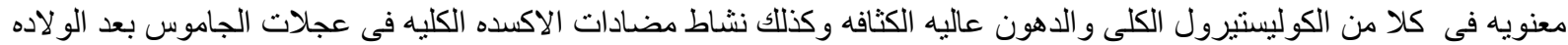

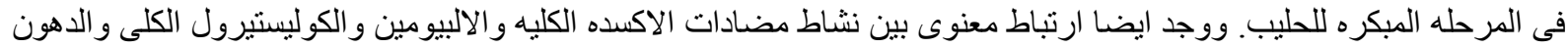
عاليه الكثافه. 